\title{
Point-to-Point Feedback Control of a Trident Snake Robot*
}

\author{
Masato IsHIKAWA $^{\dagger}$, Yuki MinAmi ${ }^{\dagger}$ and Toshiharu SugIE $^{\dagger}$
}

\begin{abstract}
This paper is concerned with point-to-point feedback control of a trident snake robot. The robot is proposed in our recent work as a new example of nonholonomic systems with two generators. In this paper, a new feedforward type periodic algorithm is proposed to achieve smooth and quantitative locomotion of the robot. Then, a periodic feedback control method is also given which drives the state of the robot to a desired one. The proposed methods are examined by numerical simulations and experiments.
\end{abstract}

\section{1.はじめに}

三叉へビ型ロボットとは，著者らが提案してきた新し い移動原理に基づく車輪型移動ロボットである $[1,2]$. 中 央のベースリンクに従来のへビ型ロボットを三叉状に連 結することで構成されている，このロボットは，速度拘 束を有する非ホロノミックシステムであり，その運動学 モデルは 2 ジェネレータ drift-free システムとよばれる 非線形状態力程式で表される。

Drift-free システムは連続な状態フィードバックによ る漸近安定化が不可能であるため $[3]$, 不連続あるいは時 変状態フィードバックによるアプローチの格好の題材と して扱われてきた. なかでも chained form や時間軸状 態制御形などに代表される 1 ジェネレータのシステムに 関しては, 盛んに研究が行われ，その制御方法の本質は お扮むね解決されている [4]. 一方, 2 ジェネレー夕 [5] と よばれるクラスのシステムについてはまだ少数の研究が あるのみで（文献 $[6,7]$ および文献 [5] の参考文献参照）, 非線形制御の観点からみてきわめて興味深い対象である. 先行研究で著者らは, まず 3 入力の 2 ジェネレータ のプロトタイプとして 1 リンクの三叉ヘビ型ロボットを 考案し, ベキ零近似と時間軸状態制御系に基づく切り替

\footnotetext{
* 原稿受付 2006 年 4 月 20 日

†京都大学 大学院 情報学研究科 Graduate School of Informatics, Kyoto University; Gokasho, Uji city, Kyoto 611-0011, JAPAN

Key Words: nonholonomic system, nonlinear system, mobile robot.
}

え制御法により, 原点近傍で有効なフィードバック制御 を実現した[1]. しかしながらこの方法では, 目標状態付 近での微調整には適しているが，大きな移動を目的とし た並進や回転運動は困難であった。そこで著者らは，可 制御性解析とホロノミーの原理に基づいてこの機構の推 進原理を明らかにし, 単純な定数入力と周期入力を組み 合わせることにより，回転運動と並進運動をそれぞれ実 現するフィードフォワード制御を提案した $[2]$.

本論文では，文献 [2] で考慮されていなかった二つの 問題点に取り組み，1 リンク型の三叉ヘビ型ロボットの より正確な推進運動を実現する。まず第一に, 先行研究 の方法では推進運動を実現するために, 定数入力と周期 入力を 2 段階に組み合わせる必要がある. そのため不 連続な切り替えが生じ, 滑らかな推進運動が実現できな い.また回転運動と並進運動を実行するアルゴリズム がそれぞれで異なるため, 回転と並進を同時に行うこ ともできなかった. そこで本論文では, 周期入力だけで 滑らかな推進運動を実現するためのフィードフォワード 入力の設計法を提案する. さらに，それを拡張すること で任意に指定された姿勢・位置変化を同時に実現する。 そして第二に，フィードフォワード制御のみでは正確に 目標状態に到達させることが困難であるため, フィード バック制御を併用する手法を提案する。具体的には提案 する制御方策を利用し，周期的なフィードバック制御を 行うことで, ロボットの状態を所望の状態に到達させる Point-to-Point 制御を実現する。またロボットの軌道追 従問題などに対応するため, 一回の周期入力ごとに生じ 
る誤差を周期入力のパラメータに反映させる反復修正法 を提案する。 なお, 本論文で提案する手法の有効性は, 数值シミュレーションと実機実験により検証する.

\section{2. 三叉へビ型ロボット}

\section{1 モデル設定}

本論文で扱う 1 リンク型の三叉ヘビ型ロボットの概 観を Fig. 1 に示す [8]. ベースリンクは正三角形であり， その三つの頂点には受動車輪のついた足（リンク）が 駆動関節を介して接続されている。ベース中心から関 節までの距離および関節から車輪までの距離はいずれ も $10[\mathrm{~cm}]$ であり，関節駆動用のアクチュエータには Hitech 製 R/C サーボモータ（HSR-5995TG, Speed: 0.15 [sec $/ 60^{\circ}$ ], Torque: $24[\mathrm{~kg} \cdot \mathrm{cm}]$ ) を使用している.

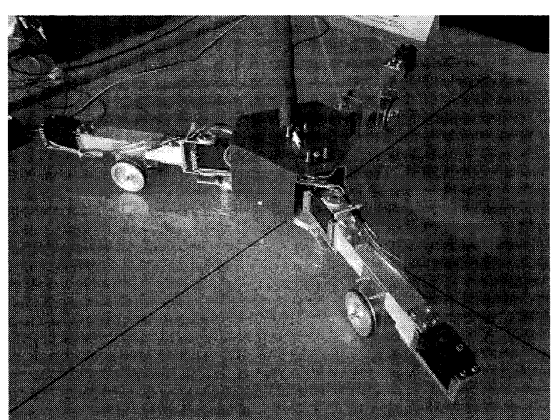

Fig. 1 Trident snake robot

本論文では，このロボットを Fig. 2 に示すようなモデ ルとして考える。そして，ロボットは平坦な地面に置か れているものとし，運動はすべて平面上で考える．さら に簡単のため, ベースリンク中心から各頂点までの距離 を 1 , 各関節から車輪までの距離を 1 とし，2 番目の足 が連結されている頂点の方向をべースの正面とする．口 ボットの状態は, ベースの配置（位置・姿勢）を表すべ クトル $\boldsymbol{w}:=\left[x, y, \theta_{0}\right]^{\mathrm{T}}$, およびロボットの形状（各関 節の相対角度）を表すべクトル $\phi:=\left[\phi_{11}, \phi_{21}, \phi_{31}\right]^{\mathrm{T}}$ で決まる。以降では各足が放射状に開いた形状 $\phi=0$ を 基準形状とよぶことにする.

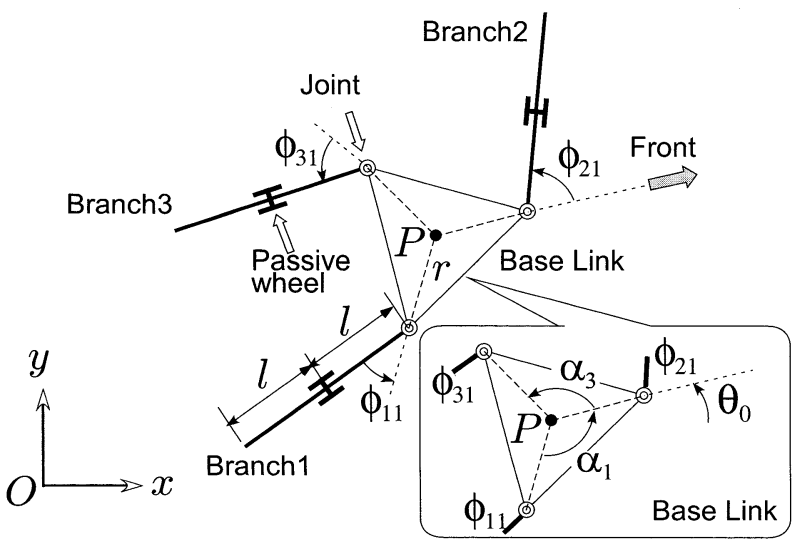

Fig. 2 Model of the trident snake robot

\section{2 運動学モデルと状態方程式の導出}

以上の設定に基づいて，まず運動学モデルを導出する. 各リンクの車輪の位置のホロノミック拘束拈よび, 車輪 が滑らないという非ホロノミック拘束により，運動学モ デルは次式となる（導出の詳細は文献 [2] を参照）.

$$
\begin{aligned}
& A(\phi) R_{\theta_{0}}^{\mathrm{T}} \dot{\boldsymbol{w}}=\dot{\boldsymbol{\phi}} \\
& R_{\theta_{0}}^{\mathrm{T}}=\left[\begin{array}{ccc}
\cos \theta_{0} & \sin \theta_{0} & 0 \\
-\sin \theta_{0} & \cos \theta_{0} & 0 \\
0 & 0 & 1
\end{array}\right]
\end{aligned}
$$

つぎに状態方程式を導出する。運動学方程式 (1) より, $A(\phi)$ は $\phi$ が特異状態の值を取らないとき正則である ため

$$
\dot{\boldsymbol{w}}=R_{\theta_{0}} A(\phi)^{-1} \dot{\boldsymbol{\phi}}
$$

を得る。これより，各関節の角速度 $\dot{\phi}$ を独立な制御入力 $\boldsymbol{u}$ として与えることができることがわかる。すなわち， ロボットの運動学の状態方程式は, $\boldsymbol{u}=\dot{\boldsymbol{\phi}}$ とおき, 状態 变数を $\boldsymbol{\xi}=\left[\begin{array}{c}\phi \\ \boldsymbol{w}\end{array}\right]$ とおくと

$$
\dot{\boldsymbol{\xi}}=\left[\begin{array}{c}
\boldsymbol{I}_{3} \\
R_{\theta_{0}} A(\boldsymbol{\phi})^{-1}
\end{array}\right] \boldsymbol{u}
$$

と表される。また，上式右辺の $6 \times 3$ 行列值関数の各列 ベクトル場を $g_{1}(\boldsymbol{\xi}), g_{2}(\boldsymbol{\xi}), g_{3}(\boldsymbol{\xi})$ とおくと

$$
\dot{\boldsymbol{\xi}}=\left[g_{1}(\boldsymbol{\xi}) g_{2}(\boldsymbol{\xi}) g_{3}(\boldsymbol{\xi})\right] \boldsymbol{u}
$$

の形の 3 入力 6 状態の対称アフィンシステムを得る.

\section{3. 速度制御入力設計法}

\section{1 先行研究の手法}

先行研究では, (5) 式に入力変換 $\boldsymbol{v}=A(\boldsymbol{\phi})^{-1} \boldsymbol{u}$ を施 した状態方程式に対して可制御性解析を行った。そして, Stokes の定理に基づく 1 階の Lie 括弧積運動を利用す ることで以下に示す周期入力と定数入力を組み合わせた 2 ステップの制御方策を提案し，回転制御と並進制御を 実現した（詳細は文献 [2]を参照）。ここで回転制御とは， ロボットの最終的な形状を基準形状に保ったまま全体の 向き $\theta_{0}$ を増減させる制御であり，並進制御とは，全体 の位置 $x, y$ を動かす制御である.

推進制御のアルゴリズム [2]

1. 状態方程式の三つの入力のうち二つを組み合わ せた単周期入力により状態を遷移させる.

2. 定数入力により基準形状に戻す.

本論文では，2 ステップで実現していた推進制御を 1 ステップで行うために，まず状態方程式 (5) に対して可 制御性解析を行う。そして，回転制御と並進制御を同時 
に実現できるような速度入力の設計法を提案する.

\section{2 可制御性の解析}

ベクトル場の集合 $G=\left\{g_{1}, g_{2}, g_{3}\right\}$ に対して, 1 階の Lie 括弧積 $g_{12}:=\left[g_{1}, g_{2}\right], g_{23}:=\left[g_{2}, g_{3}\right], g_{31}:=\left[g_{3}, g_{1}\right]$ を考えると， $G$ が生成する可制御接分布が

$$
\bar{G}=\operatorname{span}\left\{g_{1}, g_{2}, g_{3},\left[g_{1}, g_{2}\right],\left[g_{2}, g_{3}\right],\left[g_{3}, g_{1}\right]\right\}
$$

と表される. 特に $\boldsymbol{\phi}=\mathbf{0}, \theta_{0}=0$ のときは

$$
\bar{G}(\mathbf{0})=\operatorname{span}\left[\begin{array}{cccccc}
1 & 0 & 0 & 0 & 0 & 0 \\
0 & 1 & 0 & 0 & 0 & 0 \\
0 & 0 & 1 & 0 & 0 & 0 \\
-\frac{1}{\sqrt{3}} & 0 & \frac{1}{\sqrt{3}} & \frac{1}{6} & -\frac{1}{6} & 0 \\
\frac{1}{3} & -\frac{2}{3} & \frac{1}{3} & \frac{1}{6 \sqrt{3}} & \frac{1}{6 \sqrt{3}} & -\frac{1}{3 \sqrt{3}} \\
-\frac{1}{6} & -\frac{1}{6} & -\frac{1}{6} & \frac{1}{3 \sqrt{3}} & \frac{1}{3 \sqrt{3}} & \frac{1}{3 \sqrt{3}}
\end{array}\right]
$$

となり, $\operatorname{dim} \bar{G}(\mathbf{0})=6$ が成り立つ. またこの構造からわ かるように，Lie 括弧積運動により，単周期入力を与え ることでロボットの形状を基準形状に保ったまま姿勢を 変化させることができる，たとえば，周期入力

$$
\boldsymbol{u}(t)=[-A \omega \sin \omega t, A \omega \cos \omega t, 0]^{\mathrm{T}}
$$

を与えると $g_{12}(\mathbf{0})$ の方向に状態が遷移する．またその 推進量は $\pi A^{2}$ に比例する值にほほ等しい [2].

\section{3 速度入力の設計}

1 ステップで推進制御を達成するために，入力 $\boldsymbol{u} に$ 適当な変換を施すことを考える，すなわち，所望の状態 変位を得るような Lie 括弧積運動の組合せを見つけ，そ れを実現するような制御入力 $\boldsymbol{u}$ を決定する．以下では, まず任意方向への並進制御について議論する。

まず，入力 $\boldsymbol{u}$ がつぎのように 2 入力の $\bar{u}$ で決まると する。

$$
\boldsymbol{u}=\left[\begin{array}{ll}
K_{11} & K_{21} \\
K_{12} & K_{22} \\
K_{13} & K_{23}
\end{array}\right] \overline{\boldsymbol{u}}
$$

すると， $\bar{u}$ を入力とする状態方程式として

$$
\dot{\boldsymbol{\xi}}=\left[\begin{array}{ll}
\bar{g}_{1} & \bar{g}_{2}
\end{array}\right] \overline{\boldsymbol{u}}
$$

を得る。ただし， $\bar{g}_{1}, \bar{g}_{2}$ は，入力ベクトル場 $g_{1}, g_{2}, g_{3}$ の線形結合として次式で表される.

$$
\bar{g}_{1}=\sum_{i=1}^{3} K_{1 i} g_{i}, \quad \bar{g}_{2}=\sum_{i=1}^{3} K_{2 i} g_{i}
$$

任意の進行方向へ並進させるには, 状態変位として $\boldsymbol{\xi}_{T}=[0,0,0, \cos \beta, \sin \beta, 0]^{\mathrm{T}}$ が得られればよい.ここで $\beta$ は，進行方向 ( $x$ 軸となす角) を決定する定数である. そして, 周期関数

$$
\overline{\boldsymbol{u}}=\left[\bar{u}_{1}, \bar{u}_{2}\right]^{\mathrm{T}}=[-A \omega \sin \omega t, A \omega \cos \omega t]^{\mathrm{T}}
$$

を考えると, 二つのベクトル場 $\bar{g}_{1}, \bar{g}_{2}$ の 1 階の Lie 括 弧積の効果により状態を $\boldsymbol{\xi}_{T}$ に遷移させることができる. すなわち,

$$
\boldsymbol{\xi}_{T} \simeq\left[\sum_{i=1}^{3} K_{1 i} g_{i}, \sum_{i=1}^{3} K_{2 i} g_{i}\right]
$$

と表せる。さらに上式右辺は, Lie 括弧積の歪対称性を 用いると

$$
\left[\sum_{i=1}^{3} K_{1 i} g_{i}, \sum_{i=1}^{3} K_{2 i} g_{i}\right]=\kappa_{12} g_{12}+\kappa_{23} g_{23}+\kappa_{31} g_{31}
$$

となる.ただし， $\kappa_{12}=K_{11} K_{22}-K_{12} K_{21}, \kappa_{23}=K_{12} K_{23}$ $-K_{13} K_{22}, \kappa_{31}=K_{13} K_{21}-K_{11} K_{23}$ である. (7) 式お よび (13), (14) 式を用いると, つぎの関係式を得る.

$$
\left[\begin{array}{c}
\cos \beta \\
\sin \beta \\
0
\end{array}\right]=\left[\begin{array}{ccc}
\frac{1}{6} & -\frac{1}{6} & 0 \\
\frac{1}{6 \sqrt{3}} & \frac{1}{6 \sqrt{3}} & -\frac{1}{3 \sqrt{3}} \\
\frac{1}{3 \sqrt{3}} & \frac{1}{3 \sqrt{3}} & \frac{1}{3 \sqrt{3}}
\end{array}\right]\left[\begin{array}{l}
\kappa_{12} \\
\kappa_{23} \\
\kappa_{31}
\end{array}\right]
$$

したがって， $\kappa_{12}, \kappa_{23}, \kappa_{31}$ が満たすべき条件は

$$
\left[\begin{array}{l}
\kappa_{12} \\
\kappa_{23} \\
\kappa_{31}
\end{array}\right]=\left[\begin{array}{c}
3 \cos \beta+\sqrt{3} \sin \beta \\
-3 \cos \beta+\sqrt{3} \sin \beta \\
-2 \sqrt{3} \sin \beta
\end{array}\right]
$$

となる。

つぎに，この $\kappa_{12}, \kappa_{23}, \kappa_{31}$ から $K_{1 i}, K_{2 i},(i=1,2,3)$ を決める。これは,

$$
\begin{aligned}
& \boldsymbol{\kappa}=\left[\kappa_{12}, \kappa_{31}, \kappa_{23}\right]^{\mathrm{T}} \\
& \boldsymbol{K}_{j}=\left[K_{j 1}, K_{j 2}, K_{j 3}\right]^{\mathrm{T}}, j=1,2
\end{aligned}
$$

としたときの $\boldsymbol{\kappa}=\boldsymbol{K}_{1} \times \boldsymbol{K}_{2}=\hat{\boldsymbol{K}}_{1} \boldsymbol{K}_{2}$ を満たす， $\boldsymbol{K}_{1}$ ， $\boldsymbol{K}_{2}$ を見つけることと同じである.ここで，

$$
\hat{\boldsymbol{K}}_{1}=\left[\begin{array}{ccc}
-K_{12} & K_{11} & 0 \\
K_{13} & 0 & -K_{11} \\
0 & -K_{13} & K_{12}
\end{array}\right]
$$

である.しかしながら，ベクトル積が $\boldsymbol{\kappa}$ となる， $\boldsymbol{K}_{1}, \boldsymbol{K}_{2}$ の組合せは一意ではなく，決め方には自由度がある．た だし， $\boldsymbol{K}_{1}, \boldsymbol{K}_{2}$ は $\boldsymbol{\kappa}$ に直交し，互いに平行でないこと が必要である。そこでまず， $K_{1}$ を $\boldsymbol{\kappa}$ に直交するように 適当に定める（たとえば $\boldsymbol{K}_{1}=[1,1,1]^{\mathrm{T}}$ と選べばよい）. さらに， $\boldsymbol{K}_{1}$ と $\boldsymbol{K}_{2}$ の内積の大きさを $\boldsymbol{K}_{1} \cdot \boldsymbol{K}_{2}=c$ と決 める (本論文では, $c=0$ とし，二つのベクトルが直交 するようにする)。そして，

$$
\left[\begin{array}{c}
\boldsymbol{\kappa} \\
c
\end{array}\right]=\left[\begin{array}{c}
\hat{\boldsymbol{K}}_{1} \\
\boldsymbol{K}_{1}^{\mathrm{T}}
\end{array}\right] \boldsymbol{K}_{2}=: \boldsymbol{K} \boldsymbol{K}_{2}
$$


より, $\boldsymbol{K}_{2}$ を

$$
\boldsymbol{K}_{2}=\boldsymbol{K}^{+}\left[\begin{array}{l}
\boldsymbol{\kappa} \\
c
\end{array}\right]
$$

と決める。ここで $\boldsymbol{K}^{+}$は行列 $\boldsymbol{K}$ の疑似逆行列である. 以上で $K_{1 i}, K_{2 i},(i=1,2,3)$ が求まったので，あとは, $\overline{\boldsymbol{u}}$ を満足する入力 $\boldsymbol{u}$ が $(9)$ 式により求まる.

実際， $\boldsymbol{K}_{1}=[1,1,1]^{\mathrm{T}}$ とすれば,

$$
\boldsymbol{K}_{2}=\left[\begin{array}{c}
-\cos \beta-\sqrt{3} \sin \beta \\
2 \cos \beta \\
-\cos \beta+\sqrt{3} \sin \beta
\end{array}\right]
$$

となり， $\beta$ の方向に並進させるための制御入力 $\boldsymbol{u}$ とし て次式を得る。

$$
\left\{\begin{array}{l}
u_{1}=A \omega(-\sin \omega t-(\cos \beta+\sqrt{3} \sin \beta) \cos \omega t) \\
u_{2}=A \omega(-\sin \omega t+2 \cos \omega t \cos \beta) \\
u_{3}=A \omega(-\sin \omega t-(\cos \beta-\sqrt{3} \sin \beta) \cos \omega t)
\end{array}\right.
$$

Fig. 3 に $A=0.3, \omega=4[\mathrm{rad} / \mathrm{s}]$ としたときの並進制 御 $(\beta=0)$ のシミュレーション結果を示す. 図は, ロボッ トの位置 $x, y$ および姿勢 $\theta_{0}$ の時間応答を示している. これより，一回の周期入力（約 $1.57[\mathrm{sec}] ）$ をえると, ロボットの位置 $y$ (破線) および姿勢 $\theta_{0}$ (一点鎖線) が ほぼ初期状態に戻り，ロボットの位置 $x$ (実線) のみが 増加していることが確認できる。 そして, 周期入力を 6 回繰り返すことにより約 1.7 単位長の並進を実現してい る。また，このときロボットの形状は基準形状のままで ある。

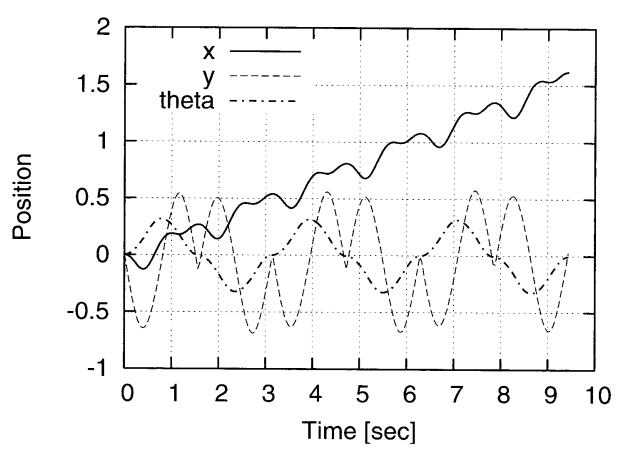

Fig. 3 Simulation result (Translation, $\beta=0$ )

また，回転制御の場合も並進制御と同様の操作で制御入 力を決定することができる. 1 ステップで, $\left[0,0,0,0,0, \Delta \theta_{0}\right]^{\mathrm{T}}$ の変位を得るとすれば， $\kappa$ が

$$
\kappa=\left[\sqrt{3} \Delta \theta_{0}, \sqrt{3} \Delta \theta_{0}, \sqrt{3} \Delta \theta_{0}\right]^{\mathrm{T}}
$$

となる.そして, $\boldsymbol{K}_{1}=[1,-2,1]^{\mathrm{T}}$ ととれば，

$$
\boldsymbol{K}_{2}=\left[\frac{\sqrt{3} \Delta \theta_{0}}{2}, 0,-\frac{\sqrt{3} \Delta \theta_{0}}{2}\right]^{\mathrm{T}}
$$

となり，入力 $\boldsymbol{u}$ として次式を得る。

$$
\left\{\begin{array}{l}
u_{1}=A \omega\left(-\sin \omega t+\frac{1}{2} \sqrt{3} \Delta \theta_{0} \cos \omega t\right) \\
u_{2}=2 A \omega \sin \omega t \\
u_{3}=A \omega\left(-\sin \omega t-\frac{1}{2} \sqrt{3} \Delta \theta_{0} \cos \omega t\right)
\end{array}\right.
$$

Fig. 4 に, $\Delta \theta_{0}=2, A=0.15, \omega=4[\mathrm{rad} / \mathrm{s}]$ とした ときのシミュレーション結果（位置 $x, y$ および姿勢 $\theta_{0}$ の時間応答）を示す。これより, 一回の周期入力（約 $1.57[\mathrm{sec}]$ ）を与えると，ロボットの位置 $x, y$ （実線およ び破線）がほぼ初期状態に戻り，ロボットの姿勢 $\theta_{0}$ (一 点鎖線）のみが増加していることが確認できる。 そして， 周期入力を 6 回繰り返すことにより，1 [ $\mathrm{rad}]$ 程度の回 転を実現している。

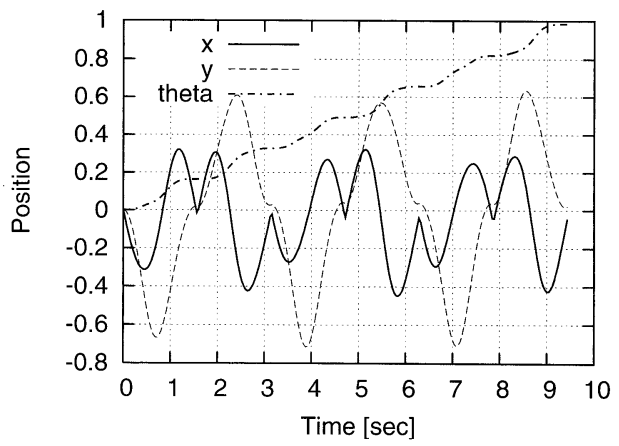

Fig. 4 Simulation result (Rotation)

以上の並進制御と回転制御の場合と同様に 1 ステップ で並進と回転を同時に実現する場合の制御入力を求める ことができるが，式が煩雑になるためここでは割愛する．

\section{4. 周期フィードバック制御}

\subsection{Point-to-Point フィードバック制御}

前節の入力設計で周期入力のみで回転制御と並進制 御が実現できるようになった。本論文ではつぎに，こ れらの制御方策を用い，周期的なフィードバック制御 を行うことでロボットの状態を目標状態に到達させる Point-to-Point 制御を実現する．以下では，簡単のため 並進制御のみを用いた制御を考える。

フィードバック制御では，目標とする状態と現在 の状態との偏差を周期入力のパラメータである振幅 $A$ と進行方向 $\beta$ に比例させる. 振幅 $A$ の計算方法 は, 一回の周期入力により得られる変位が $(\Delta x, \Delta y)=$ $\left(\pi A^{2} \cos \beta, \pi A^{2} \sin \beta\right)$ で近似できることを用いて，

$$
\begin{aligned}
& A=\sqrt{\frac{1}{\pi}\left\{\left(x_{d}-x(t)\right) \cos \beta+\left(y_{d}-y(t)\right) \sin \beta\right\}} \\
& \text { If } A>A_{\max }, \text { then } A=A_{\max }
\end{aligned}
$$

とした。ただし， $x_{d}, y_{d}$ は目標状態の $(x, y)$ 座標であ り，振幅の最大值 $A_{\max }$ を設定しているのは，目標状態 の選び方により，振幅が大きくなりすぎるのを防ぐため である。また， $\beta$ については 


$$
\beta=\tan ^{-1}\left(\frac{y_{d}-y}{x_{d}-x}\right)
$$

で計算する。実際，目標状態を $[0,0,0,1.5,0,0]^{\mathrm{T}}$ とした ときのシミュレーションおよび実験結果を Figs. 5,6 に 示す。ただし，周期入力の振幅の最大值を $A_{\max }=0.2$, 周波数を $\omega=4[\mathrm{rad} / \mathrm{s}]$ とした. Fig. 5 はロボットの位 置 $x, y$ および姿勢 $\theta_{0}$ の時間応答を示しており，周期入 力（約 1.57 [sec]）を繰り返すことで，ロボットの状態が 目標状態に収束していることが確認できる．位置 $y$ （破 線）に関しては，並進する際に負方向へのドリフトが見 られるが，フィードバック制御により最終的に目標状態 に収束していることがわかる．そして，Fig. 6 は制御入 力の振幅 $A$ 拈よび進行方向 $\beta$ の変化の様子を示してい る。これより, 状態が目標状態に近づくにしたがって， 周期入力の振幅 $A$ (実線) が 0 に収束していくことが確

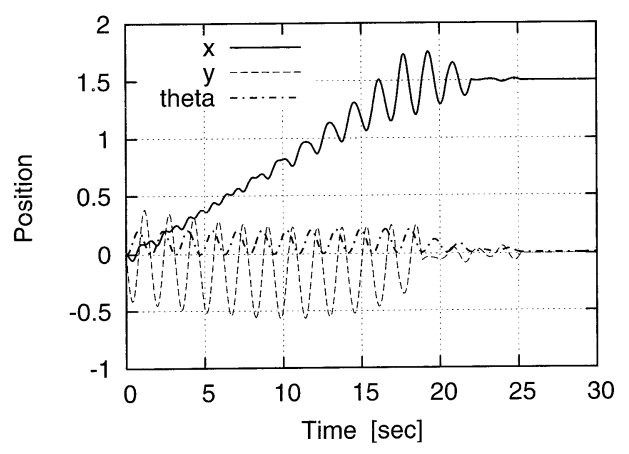

(a) Simulation

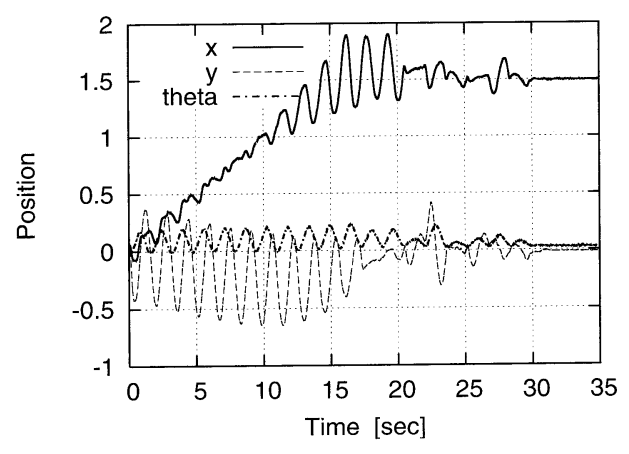

(b) Experiment

Fig. 5 PTP Control

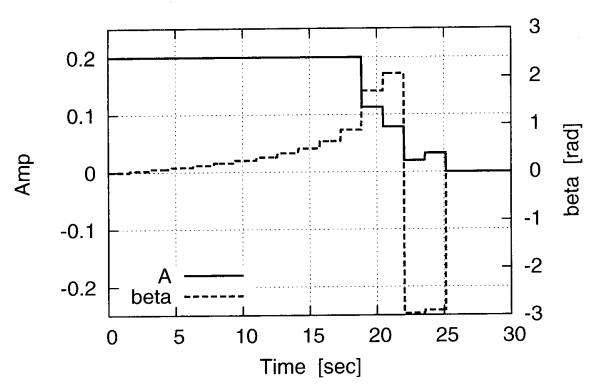

Fig. 6 Parameter of periodic input
認できる。また， $\beta=0$ の並進運動を実行しているにも かかわらず， $\beta$ の值 (破線) が変動しているのは, 上述 した $y$ 方向へのドリフトを修正しているためである.

(注意 1) Point-to-Point フィードバック制御則の安 定性について述べておく。推進制御では，周期入力一回 ごとの近似変位量（(13) 式の右辺）が振幅の 2 乗 $\left(A^{2}\right)$ に比例し, 誤差は 3 乗以上のオーダ $\left(O\left(A^{3}\right)\right)$ になる [2]. つまり状態 $\xi$ は，振幅 $A$ が十分小さければ，たとえ誤差 があったとしても初期状態よりは目標状態に近いところ に遷移する。したがって，振幅 $A$, 進行方向 $\beta$ の更新と 周期入力を繰り返せば，状態は目標状態に収束する.

\section{2 反復修正を用いた軌道追従制御}

Point-to-Point 制御により, 周期入力により生じる誤 差を吸収し, 目標状態に達成させることができた。つぎ に目標状態が遠い場合や，軌道追従問題を考える。まず, 一定速度での正確な並進制御を実現させる。ここでは, 現在のロボットのベース中心位置を $(x, y)$ としたとき， つぎの目標值として一回の周期入力でたどり着ける值よ り大きなものを選び， $(x+0.2, y)$ と設定する。このよ うに目標值を一定間隔で動かすことにより，一定速度の 並進ができる、いま，ロボットの初期位置を $(0,0)$ とし $x$ 軸上をまっすぐ並進させたときのシミュレーションお よび実験結果を Fig. 7 に示す。この図は周期入力を 20 セット行った結果であり, ベース位置の $x-y$ 平面の運 動を表している。また図中の丸印は 1 セットごとのベー

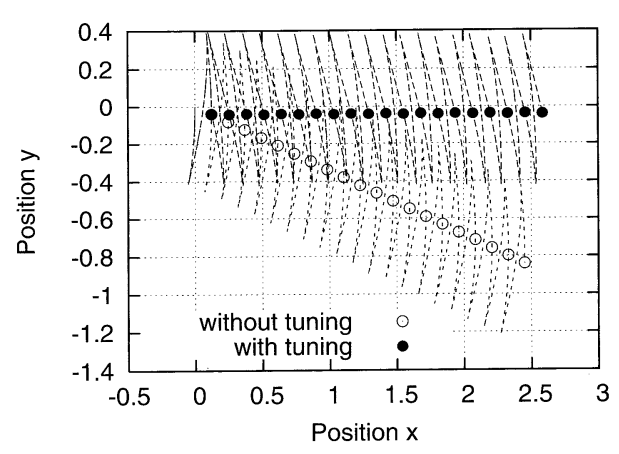

(a) Simulation

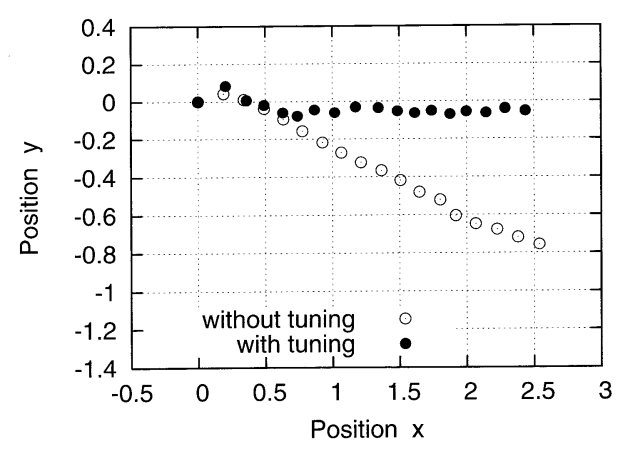

(b) Experiment

Fig. 7 Path tracking control 
ス位置である。これより，フィードバック制御だけでは， 周期入力によって生じる誤差が $y$ 軸方向に蓄積されてい き，所望の方向へ直進することができないことが確認で きる（白丸）。そこで本論文では，1 セットごとに生じ る誤差を周期入力のパラメータである $\beta$ に反映させる ことで，誤差を除去する反復修正法を提案する.

まず，目標とする進行方向を $\beta$ とする。そして，一周 期を $\Delta t:=2 \pi / \omega$ とするとき，実際にロボットが進んだ 方向が

$$
\tan ^{-1}\left(\frac{y(t)-y(t-\Delta t)}{x(t)-x(x-\Delta t)}\right)
$$

となることから，進行方向の誤差がつぎのように表さ れる。

$$
\Delta \beta=\beta-\tan ^{-1}\left(\frac{y(t)-y(t-\Delta t)}{x(t)-x(x-\Delta t)}\right)
$$

つぎの試行において $\beta$ 方向に進行させる場合，あらかじ め前回の試行で生じた誤差 $\Delta \beta$ を加えた方向に進行させ ることで，䛊差を低減することができると考えられる， したがって，目標とする方向に $\Delta \beta$ を加えた

$$
\beta=\tan ^{-1}\left(\frac{y_{d}-y}{x_{d}-x}\right)+\Delta \beta
$$

の值を用いることにする.

この方法を用いて前述の軌道追従実験を行った結果が, Fig. 7 の黒丸で表されるものである．各試行ごとに修正 を行うことで, 誤差が蓄積せず, $x$ 軸と並行に直進して いることが確認できる. $x$ 軸上を移動していないのは, 1 回目の試行のときに生じた誤差が残っているためである.

つぎに $x$ 軸上を並進させることを考える。すなわち， 1 試行ごとの目標值を $(x+0.2,0)$ とする. そして, 誤差 修正を用いて周期入力を 30 セット繰り返すシミュレー ションおよび実験を行った。 その結果を Fig. 8 に示す. たたし，初期位置を $(0,1)$ とし，図中の丸印は，1 セッ トごとのベース位置を表している。まず，修正なしの場 合は，フィードバック制御により $x$ 軸に近づいてはいる が，シミュレーションおよび実験結果ともに 0.06 単位 長程度のオフセットが生じ， $x$ 軸上を並進することがで きていない.これは, フィードバック制御で $x$ 軸に近付 こうとする周期入力を決定しているが，実際に得られる 変位に誤差が生じてしまうためである。これに対して， 修正を用いると，誤差なく $x$ 軸上を並進できていること が確認できる。

なお，反復修正を用いた軌道追従制御の安定性および パラメータ $A, \beta$ の収束性は自明でなく，厳密な証明が 今後の課題として残されている点を付記しておく.

\section{5. おわりに}

本論文では，まず先行研究で用いていた入力変換を必 要としない形で可制御性解析を行い, 周期入力だけで並

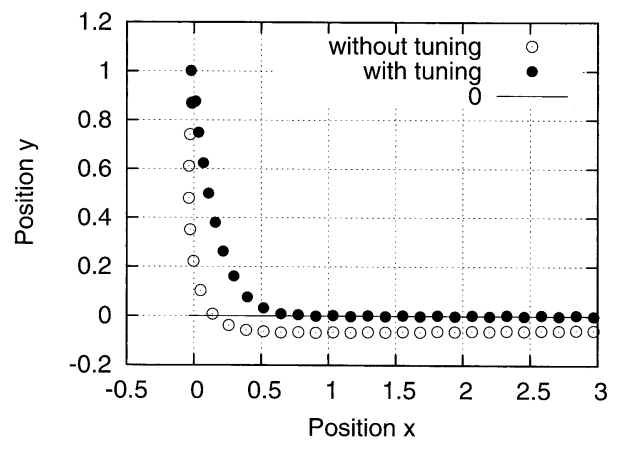

(a) Simulation

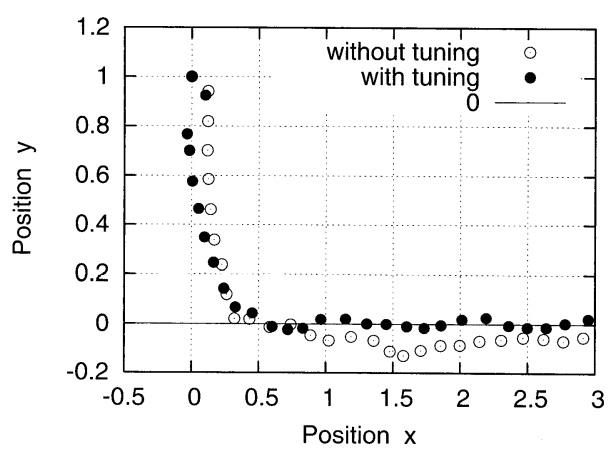

(b) Experiment

Fig. 8 Path tracking control

進および回転制御を実現する周期入力の設計法を提案し た. そして, 先行研究で別々の運動として扱っていた回 転と並進を同時に実現した。さらにこの制御方策を用い た周期フィードバック制御を提案し，シミュレーション および実機実験によりロボットの Point-to-Point 制御を 実現した。また，一回の周期入力によって生じる誤差を 次回の試行に反映させる䛊差修正法を提案し, 計画した 軌道上に沿って並進させる軌道追従を実現した。

\section{謝辞}

本研究は, 文部科学省科学研究費補助金 (若手研究 (B)No. 17760349）による支援を受けて行われた。ここ に感謝の意を表する。

\section{参 考文 献}

[1] 岩谷, 石川, 原：三叉へビ型移動ロボットの運動解析 と制御 ; 計測自動制御学会論文集，Vol. 39, No. 12, pp. 1159-1161 (2003)

[2] 石川:三叉へビ型ロボットの推進原理と周期入力による制 御 ; 計測自動制御学会論文集, Vol. 42 , No. 5 , pp. 520 528 (2006)

[3] R. W. Brockett: Asymptotic stability and feedback stabilization; Differential Geometric Control Theory, Vol. 27, pp. 181-191, Springer Verlag (1983)

[4] 三平：非ホロノミックシステムのフィードバック制御 ; 計測と制御, Vol. 36, No. 6, pp. 396-403 (1997) 
[5] 石川：非ホロノミックシステムの位相構造一未解決問題へ の誘い；システム/制御/情報, Vol. 45 , No. 9, pp. 536$543(2001)$

[6] 岩谷, 石川, 原：一次の可制御構造を持つ対称アフィ ン系のフィードバック制御一時間軸状態制御系に基づく 切り替え制御戦略一; 計測自動制御学会論文集,Vol. 38, No. 10, pp. 839-844 (2002)

[7] 浦久保, 土屋, 辻田：あるクラスの非ホロノミックシス テムに対するリャプノフ制御; 計測自動制御学会論文集, Vol. 37, No. 11, pp. 1020-1025 (2001)

[8] M. Ishikawa, Y. Minami and T. Sugie: Development and control experiment of the trident snake robot; Proc. of the 45th IEEE Conference on Decision and Control, pp. 6450-6455 (2006) 